\title{
Age determination of paleotsunami sediments around Lombok Island, Indonesia, and identification of their possible tsunamigenic earthquakes
}

\author{
Aswan · Yahdi Zaim - Yan Rizal - I. Nyoman Sukanta • Suci Dewi Anugrah • \\ Agus Tri Hascaryo - Indra Gunawan - Tatok Yatimantoro • Weniza • \\ Hidayanti · Purnomo Hawati $\cdot$ Wahyu Dwijo Santoso $\cdot$ Nurochim
}

Received: 21 April 2016/Accepted: 31 March 2017/Published online: 20 May 2017

(C) The Author(s) 2017. This article is an open access publication

\begin{abstract}
Age determination of paleotsunami sediment from Lombok Island, Indonesia, and surrounding area has been carried out using the ${ }^{210} \mathrm{~Pb}$ method in BATAN Jakarta. The basic theory of this method assumes that weathering of sediments, including paleotsunami sediments, will result in ${ }^{210} \mathrm{~Pb}$ enrichment. The principle of this method is to calculate ${ }^{210} \mathrm{~Pb}$ contents accumulation in a particular sedimentation interval from the surface to the deeper buried sediments. The results are then converted into age or depositional time in years ago unit. The dating results from the paleotsunami sediments of the Gawah Pudak (S8 $\left.46^{\prime} 2.91^{\prime \prime}, \mathrm{E} 115^{\circ} 56^{\prime} 34.23^{\prime \prime}\right)$ and Gili Trawangan areas $\left(\mathrm{S}^{\circ} 21^{\prime} 1.38^{\prime \prime}, \mathrm{E} 116^{\circ} 2^{\prime} 36.6^{\prime \prime}\right)$ indicate the Gawah Pudak sediments were deposited 37 years ago (c. in 1977) and 22 years ago (c. in 1992). Three paleotsunami sediments from Gili Trawangan were deposited 149 years ago (c. in 1865), 117 years ago (c. in 1897) and 42 years ago (c. in 1972). These results are then compared to the available Indonesian earthquake catalogue data. This study reveals that paleotsunami sediments around Lombok Islands, from older to younger, were caused by the 1857 earthquake (epicentre in Bali Sea; $M 7$; $\mathrm{S} 8^{\circ} 00^{\prime} 09.45^{\prime \prime}$, E115 $29^{\prime} 56.41^{\prime \prime}$ ), 1897 earthquake (epicentre in Flores Sea; M5.5; $\mathrm{S}^{\circ} 47^{\prime} 59.62^{\prime \prime}, \quad \mathrm{E} 120^{\circ} 48^{\prime} 03.5^{\prime \prime}$ or Sulu Sea
\end{abstract}

\footnotetext{
Aswan $(\bowtie) \cdot$ Y. Zaim · Y. Rizal · A. T. Hascaryo .

W. D. Santoso $\cdot$ Nurochim

Geology Department, Institute of Technology Bandung (ITB),

Jl. Ganesha 10, Bandung 40132, Indonesia

e-mail: aswan_gl@gc.itb.ac.id

I. N. Sukanta · S. D. Anugrah · I. Gunawan ·

T. Yatimantoro · Weniza · Hidayanti · P. Hawati

Tsunami Mitigation Division - Meteorological Climatological and Geophysical Agency (BMKG), Jl. Angkasa 1 no 2

Kemayoran, Jakarta 10720, Indonesia
}

earthquake; $M 8.5 ; 70 \mathrm{~km} \mathrm{NW}$ of Basilan Island), the 1975

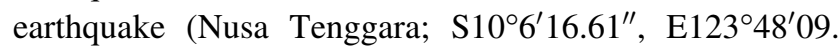
39"), 1977 earthquake (in Waingapu, Sumba; M8.0; $\left.\mathrm{S} 11^{\circ} 5^{\prime} 39.34^{\prime \prime}, \mathrm{E} 118^{\circ} 27^{\prime} 50.86^{\prime \prime}\right)$ and the 1992 earthquake (Flores; M7.8; $\mathrm{S}^{\circ} 28^{\prime} 52.11^{\prime \prime}$, E121 $53^{\prime} 44.3^{\prime \prime}$ ).

Keywords Age - Paleotsunami $\cdot$ Sediment $\cdot{ }^{210} \mathrm{~Pb}$. Earthquake

\section{Introduction}

Currently, research on paleotsunami sediment is developing in Indonesia, especially since the events of tsunami 2004 in Aceh and tsunami 2006 in Pangandaran. The term paleotsunami sediments in this study is defined as a sedimentary deposits formed as a result of the tsunami that occurred before 50 years ago. This research was carried out along the coast of Lombok island; however, since the age of tsunami deposits that can be determined is limited, tsunami deposits derived from Gawah Pudak (S8 46 $2.91^{\prime \prime}$, E115 $56^{\prime} 34.23^{\prime \prime}$ ) and Gili Trawangan ( $\mathrm{S}^{\circ} 21^{\prime} 1.38^{\prime \prime}$, E116 $\left.{ }^{\circ} 2^{\prime} 36.6^{\prime \prime}\right)$ were discussed (Fig. 1). Lombok Island has been selected for this research due to its flat beach morphologies in general; therefore, it is possible to obtain paleotsunami sediments. Lombok Island is also one of the most popular tourist destinations in Indonesia, so the research is necessary to be aware of the tsunami hazards in the future.

This paper discusses age determination of paleotsunami sediments found in the study area in order to determine the earthquake event that was related to the tsunami. The age determinations have been carried out using the ${ }^{210} \mathrm{~Pb}$ method in BATAN Jakarta. The basic theory of this method assumes that the ${ }^{210} \mathrm{~Pb}$ is enriched during the weathering of sediments including paleotsunami 


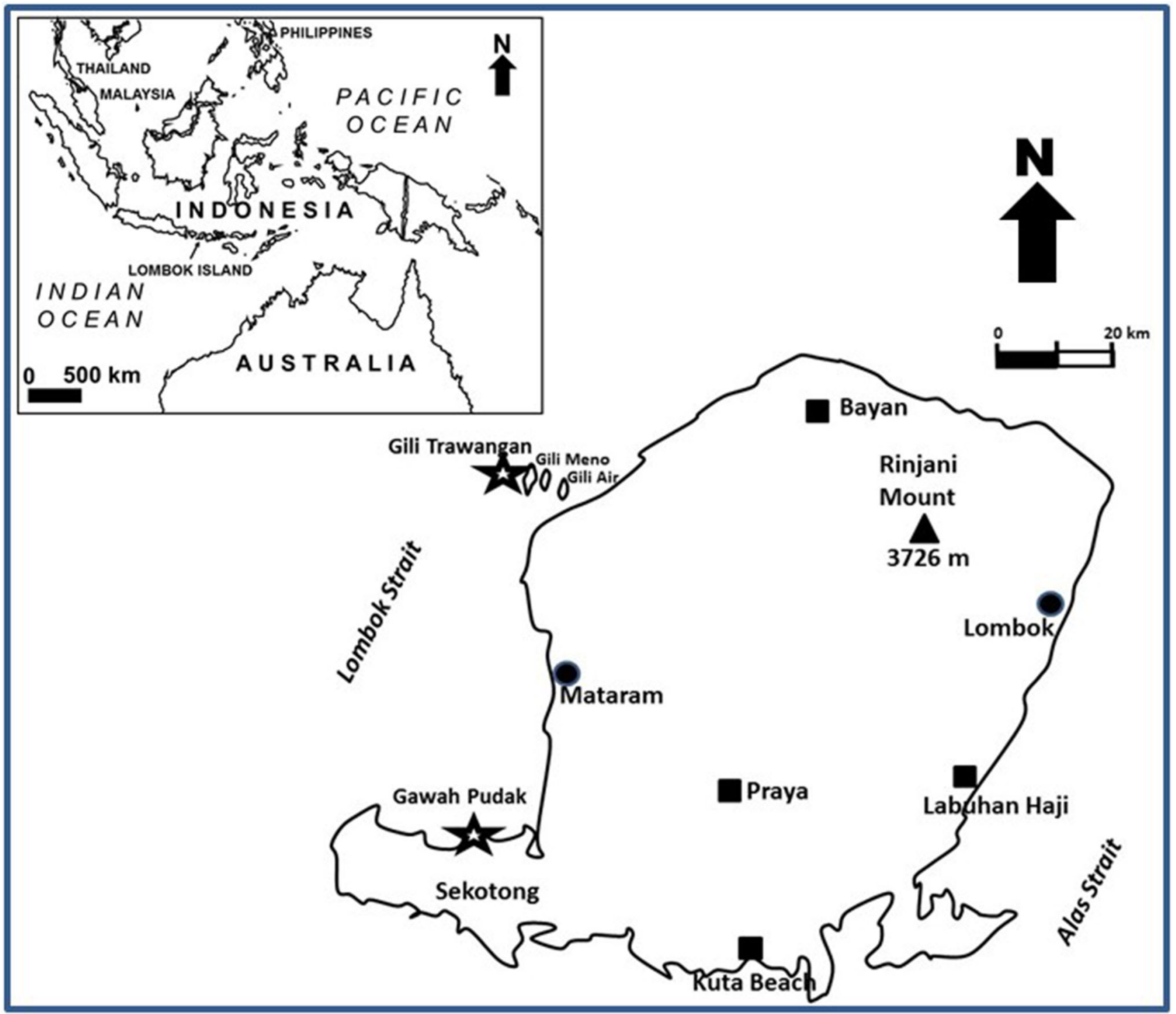

Fig. 1 Map showing observation and sampling locations (star signs; Gawah Pudak and Gili Trawangan) of the paleotsunami sediments in Lombok Island. The star is for sampling location, the circle is for big city, the square is for small city and the triangle is for volcano

sediments. The paleotsunami deposits in this study were deposited as a beach deposits from tidal to shallow marine environment. The principle of this method is to calculate the ${ }^{210} \mathrm{~Pb}$ contents accumulation of any particular sedimentary interval and convert them into age or depositional time in years ago unit. The ${ }^{210} \mathrm{~Pb}$ calculation starts from the surface and deeper buried sediments, respectively. Dating of these samples was carried out in 2014; therefore, the time unit refers to this year.

${ }^{210} \mathrm{~Pb}$ analysis is preferred in this study because it is effective in determining the age of the sediments with a range of 30-150 years (Madsen et al. 2005; Boer et al. 2006). In addition to its age range, ${ }^{210} \mathrm{~Pb}$ can detect abrupt sedimentation (Gelen et al. 2003) and the surface mixed layer (Boer et al. 2006) such as tsunami deposits. Natural ${ }^{210} \mathrm{~Pb}$ is also more appropriate to be used in the study area as it is considered to be far away from the nuclear activities, compared to the artificial ${ }^{137} \mathrm{Cs}$ method where ${ }^{137} \mathrm{Cs}$ origins from the nuclear explosion. Moreover, the ${ }^{137} \mathrm{Cs}$ method is not sensitive for abrupt sedimentation processes (Gelen et al. 2003) such as tsunami deposits.

By identifying the earthquake that deposited paleotsunami sediments, we will be able to know the magnitude of the earthquake and estimate the tsunamigenic cycle if two tsunami deposits are found in one particular location.

\section{Methods}

This study consists of three phases: field observation, laboratory test samples and data analysis. Shallow trenches in the area that potentially preserved paleotsunami deposits 
were made during field observation stage. Trenches were made about $1.5 \mathrm{~m} \times 1.5 \mathrm{~m}$ wide with a depth to groundwater about $1.5-2 \mathrm{~m}$ from the surface. The next step is sediment layers observation and to obtain sketch of the sediment layer sequence on the walls of each trench. Generally, paleotsunami sediments are relatively loose, light-coloured sandstone overlies on top of darker coloured of paleosoil layers (remnant former soil) such as surface soil (Yawsangratt et al. 2012; Rhodes et al. 2006). This is due to light-coloured sandy materials being brought from beach and shallow marine environments. Paleotsunami deposits are also characterized by massive fining-upwards and without sedimentary structure as they were deposited in a short interval. Rare parallel laminations are interpreted to occur only if there is a slower deposition during the backwash process. Tsunami deposit sedimentary structure characteristics are in contrast to storm or tidal deposit which generally consists of interbedded sandstones with foreset stratifications and planar stratifications with channel structures (Tuttle et al. 2004; Rhodes et al. 2006). Tsunami deposits also generally occur more towards landward than storm deposit (Tuttle et al. 2004).

Samples were obtained every $5-\mathrm{cm}$ interval with the same volume. Each sample interval weight was $5 \mathrm{~g}$. Sampling was performed starting from the surface level to the base of the trenches hole, including suspected paleotsunami sediments layers and paleosoil deposits. Each sample was separated for three laboratory analyses: faunal content analysis, grain size analysis and for ${ }^{210} \mathrm{~Pb}$ age dating analysis. Faunal and grain size analysis was carried out to support the field observation to determine whether the analyzed sediment is paleotsunami sediment or not. The result of faunal analysis was used to determine depositional paleoenvironmental based on benthic foraminifers content according to Rauwenda et al. (1984). It was also used to determine whether there is mixing between shallow marine and deep marine faunal, while tsunami deposits usually contain a mixture between these two faunal kinds (Dahanayake and Kulasena 2008). Grain size analysis was carried out to understand the current system that deposited paleotsunami sediment in pursuance of Visher (1969) and to determine whether the sedimentation is influenced by one or more current systems while tsunami deposits are usually deposited by more than one current system (Yawsangratt et al. 2012). The ${ }^{210} \mathrm{~Pb}$ analysis was conducted to identify the depositional age of the paleotsunami sediments. Several studies about sediment age determination based on ${ }^{210} \mathrm{~Pb}$ analysis were successfully carried out by Sanches-Cabeza et al. (1999), Arman (2006), and Arman et al. (2007).

The natural ${ }^{210} \mathrm{~Pb}$ in the sediment sample was measured with alpha spectrometer instrument. ${ }^{210} \mathrm{~Pb}$ originated as decay product of ${ }^{238} \mathrm{U}$ present in soil and rocks. When Radon gas is emitted into the air, unsupported ${ }^{210} \mathrm{~Pb}$ is subsequently formed. ${ }^{210} \mathrm{~Pb}$ binds with air particles, sinks to the earth surface and is deposited in the sediments. Conversion of ${ }^{210} \mathrm{~Pb}$ to age and sedimentation is using simple models, namely Constant Flux and Constant Sedimentation (CF/CS), Constant Initial Concentration (CIC) or Constant Rate of Supply (CRS), depending on ${ }^{210} \mathrm{~Pb}$ profile contained in the sediment (Sanches-Cabeza et al. 1999; Gelen et al. 2003; Madsen et al. 2005; Arman 2006; Boer et al. 2006; Arman et al. 2007). The ${ }^{210} \mathrm{~Pb}$ CRS model with MARs factor was applied in this research to determine accurate ages of abruptly deposited sediments, such as tsunami deposits (Boer et al. 2006). To maintain data accuracy for ${ }^{210} \mathrm{~Pb}$ measurement, samples were obtained systematically every $5-\mathrm{cm}$ depth in the same volume. All samples were then wrapped in aluminium foil as soon as possible and stored in the plastic bag to avoid external contamination such as oxidation before directly sent to the laboratory.

Madsen et al. (2005) and Boer et al. (2006) proposed that representative maximum age for ${ }^{210} \mathrm{~Pb}$ analysis is 150 years. The result from this study suggests that the oldest analyzed sample is not older than 150 years ago and thus the analyses results are representative for all the samples.

Using the absolute age of paleotsunami sediments obtained in the field, the tsunamigenic earthquake epicenter and its magnitude can be predicted. The epicenter and magnitude of the earthquake obtained from Indonesian earthquake catalogue were published by Masturyono et al. (2015) and Løvholt et al. (2012). The earthquake epicentral locations that interpreted to generate tsunami deposits on the Lombok Island are shown in Fig. 2. Tsunami cycle period on the Lombok Island and its surroundings could also be predicted based on data of time when the tsunami happened and the earthquake event related to it.

\subsection{Paleotsunami sediments from Gawah Pudak (South Lombok)}

This location is located on the river cliffs that are about $200 \mathrm{~m}$ from the beach in the Gawah Pudak village, South Lombok. Trenching was carried out at the river edge cliff and signed some sediment layers which are suspected as paleotsunami sediments (Fig. 3); they are: layer 3 located above beach deposit (layer 2) and layer 5 which overlies on the top paleosoil layer (layer 4). During field observation, micromollusc fragments were found in the paleotsunami suspect layers (layer 3 and 5). Some hand specimens as well as PVC tube core samples were also taken.

\subsection{Paleotsunami sediments from Gili Trawangan}

From the trenches (1.2 $\mathrm{m}$ deep) that were dug in the Gili Trawangan Mosque courtyard, fifteen sediments layers 


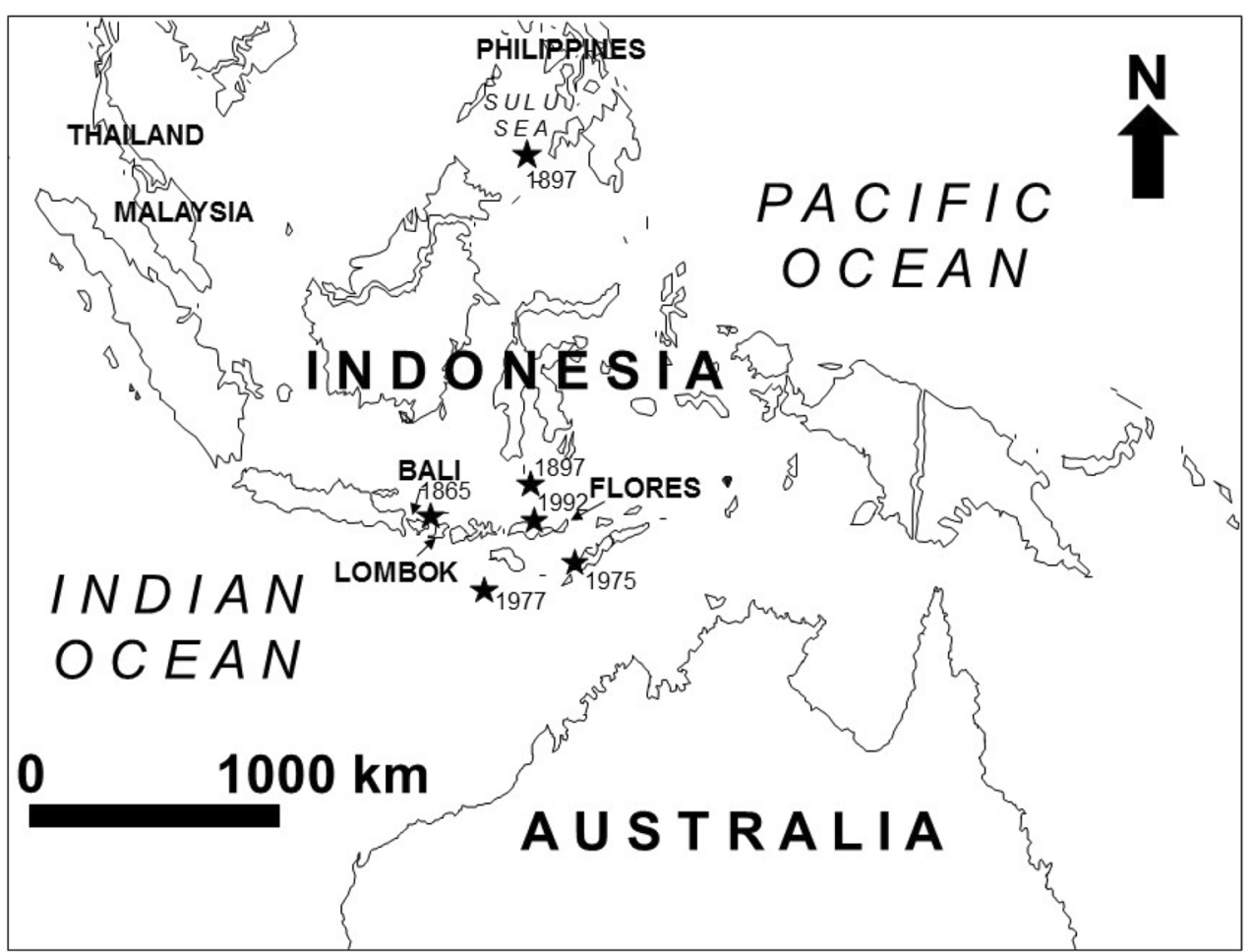

Fig. 2 Earthquake epicentral locations that generated tsunami deposits on the Lombok Island [star signs; data compiled from Løvholt et al. (2012), Masturyono et al. (2015)]

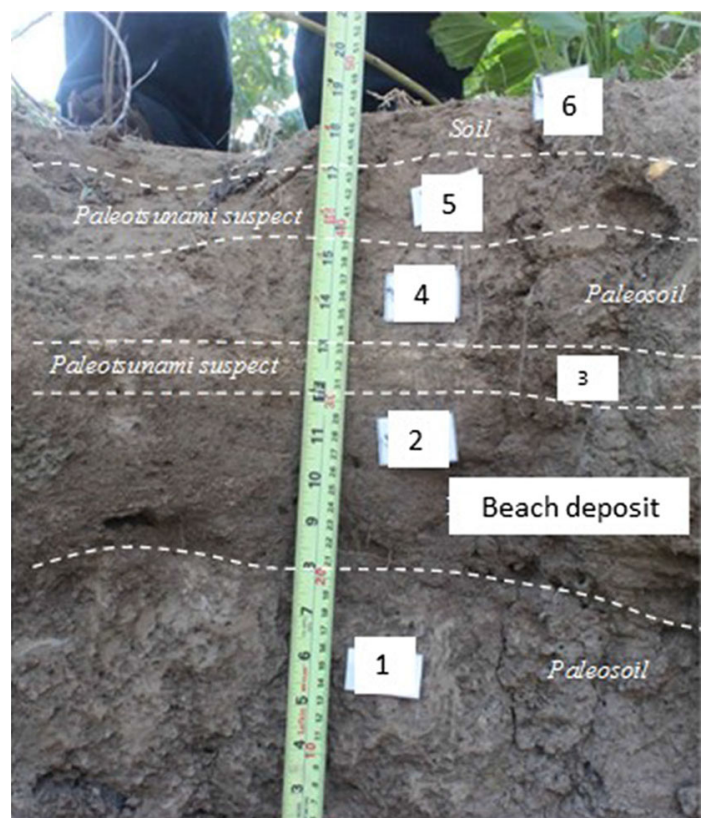

Fig. 3 Stratigraphy of the Gawah Pudak trench, South Lombok

with different thicknesses can be observed (Fig. 4). From fifteen layers which were observed, only three layers interpreted as paleotsunami sediments, i.e., layer 2, layer 5 and layer 10. These layers are light grey to brown fine sandstone, not calcareous, suspected paleotsunami

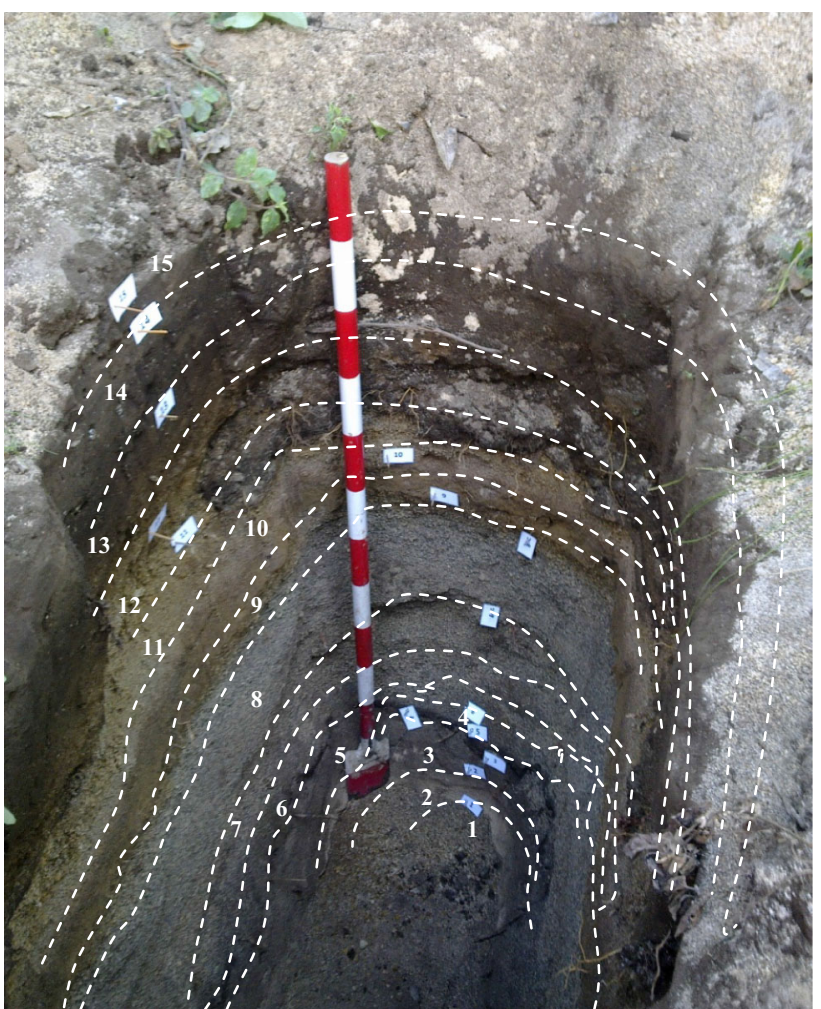

Fig. 4 Stratigraphy of the Gili Trawangan trench. Each red/white interval on the stick is $10 \mathrm{~cm}$ 
Table $1{ }^{210} \mathrm{~Pb}$ age analysis of Gawah Pudak sediments

\begin{tabular}{|c|c|c|}
\hline Layer & Age & Explanation \\
\hline 6 & 2014 & Soil (light brown clay) \\
\hline 5 & 1992 & $\begin{array}{l}\text { Tsunami Sediments (light grey loose sandstone) as } \\
\text { product of } 1992 \text { earthquake, Flores, } M 7.8 \text {; } \\
\mathrm{S}^{\circ} 28^{\prime} 52.11^{\prime \prime}, \mathrm{E} 121^{\circ} 53^{\prime} 44.3^{\prime \prime}\end{array}$ \\
\hline 4 & 1984 & Paleosoil (dark brown clay) \\
\hline 3 & 1977 & 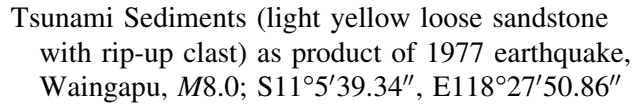 \\
\hline 2 & 1968 & Beach Deposit/River (dark brown loose sandstone \\
\hline 1 & $?$ & Paleosoil (light grey clay) \\
\hline
\end{tabular}

sediments, each overlies on top coarse sandstone layers (layers 1, 4 and 9).

\section{Discussion}

\subsection{Gawah Pudak}

Layer 3 which overlies on top beach deposit of layer 2 is loose, fine to medium light brown sandstone. Layer 5 is calcareous, loose, light brown fine to medium sandstone, overlying dark brown silty clay of paleosoil layer. Faunal analysis suggests that this layer contains Acteocina sp. (micro molluscs shell) usually found at the depth of $3 \mathrm{~m}$ and Alveolina sp. usually found at 35-50-m depth and others broken shells of Pelecypods molluscs which are also the indicator of tsunami deposit (Tuttle et al. 2004). Grain size analysis result indicates a mixture of poor-sorting fine to coarse grains as turbulent high-energy currents sediment. Faunal and grain size analyses confirm layer 5 as paleotsunami sediments as it is shown by the current turbulence which brings mixed material from deep and shallow marine. Age dating analysis of ${ }^{210} \mathrm{~Pb}$ reveals that layer 5 was deposited in 1992, most likely as a result of tsunami caused by $M 7.8$ earthquake on 12 December 1992 in the Flores Sea (S8 $28^{\prime} 52.11^{\prime \prime}$, E121 $\left.{ }^{\circ} 53^{\prime} 44.3^{\prime \prime}\right)$.

From samples in Gawah Pudak site, paleotsunami deposits in layer number 3 and 5 (Fig. 3) were deposited in 37 and 22 years ago, respectively. Each of these paleotsunami sediment ages when converted into years from old to young is 1977 and 1992, respectively. The 1977 paleotsunami deposit was triggered by the 19 August 1977 earthquake that occurred in Waingapu, Sumba (M8.0; S11 ${ }^{\prime} 39.34^{\prime \prime}$, E118 $27^{\prime} 50.86^{\prime \prime}$; Fig. 2; Table 1).

\subsection{Gili Trawangan}

In this location, faunal and grain size analyses were carried out on hand specimen from two paleotsunami sediment suspect layers (layer 5 and layer 10; Fig. 4). The faunal

Table $2{ }^{210} \mathrm{~Pb}$ age analysis of Gili Trawangan sediments

\begin{tabular}{|c|c|c|}
\hline Layer & Age & Explanation \\
\hline 15 & 2014 & Thin weathered sediments \\
\hline 14 & 2014 & Light brown clayey soil \\
\hline 13 & 2007 & Volcanic Tuff \\
\hline 12 & 1988 & Fine sand beach deposit \\
\hline 11 & 1979 & Volcanic coarse sand \\
\hline 10 & 1972 & $\begin{array}{l}\text { Tsunami sediment (light brown coarse sand with pumice fragment) as product of } 1975 \text { earthquake, Nusa Tenggara } \\
\left(\mathrm{S} 10^{\circ} 6^{\prime} 16.61^{\prime \prime}, \mathrm{E} 123^{\circ} 48^{\prime} 09.39^{\prime \prime}\right) \text { or as product of } 1977 \text { earthquake, Waingapu, } M 8,0\left(\mathrm{~S} 11^{\circ} 5^{\prime} 39.34^{\prime \prime} \text {, }\right. \\
\left.\mathrm{E} 118^{\circ} 27^{\prime} 50.86^{\prime \prime}\right)\end{array}$ \\
\hline 9 & 1970 & Tuff and pumice \\
\hline 8 & 1967 & Beach deposit fine sand \\
\hline 7 & 1965 & Calcareous beach deposit fine sand \\
\hline 6 & 1918 & Calcareous sandstone \\
\hline 5 & 1897 & $\begin{array}{l}\text { Tsunami Sediment (calcareous coarse sand with pumice fragments) as product of } 1897 \text { earthquake, Flores Sea } \\
\text { earthquake, } \\
\left.\text { M5.5 S6 } 47^{\prime} 59.62^{\prime \prime}, \mathrm{E} 120^{\circ} 48^{\prime} 03.5^{\prime \prime}\right) \text { or Sulu Sea earthquake (M8.5; } 70 \mathrm{~km} \mathrm{NW} \text { of Basilan Island) }\end{array}$ \\
\hline 4 & 1889 & Paleosoil, dark brown silt \\
\hline 3 & 1882 & Carbonaceous medium to coarse sandstone \\
\hline 2 & 1865 & $\begin{array}{l}\text { Tsunami Sediment (white loose sandstone with coral fragment) as product of } 1857 \text { earthquake in Bali Sea } M 7.0 \text {; } \\
\quad \mathrm{S} 8^{\circ} 00^{\prime} 09.45^{\prime \prime}, \mathrm{E} 115^{\circ} 29^{\prime} 56.41^{\prime \prime}\end{array}$ \\
\hline 1 & $\begin{array}{l}\text { Older than } 1865 \\
\text { (?) }\end{array}$ & White coarse sand beach deposit, calcareous, contains coral and shell fragments \\
\hline
\end{tabular}


analysis shows that sample from layer 5 contains some macrofaunal, such as Alveolina quoyii (which usually find at 40-60 m depth), Pseudorotalia sp. (5-10 m), Ammonia sp. (0-5 m), Alvania arubensis (micromollusc), and coral fragments. Based on microfaunal content, layer 5 is concluded as paleotsunami sediment that brought material from different depths up to $60 \mathrm{~m}$ mixed with shallow marine fauna. Layer 10 contains no microfaunal fossil (barren). Grain size analysis of layer 3, 5 and 10 sediment samples suggests a combination of poor-sorting, medium to very coarse grains. This grain size mixture is interpreted as a result of initial current which deposited fine to medium grain which was then mixed with coarse material brought by backwash current. This current reverse is likely to occur by the current caused by tsunami.

${ }^{210} \mathrm{~Pb}$ analysis (Table 2). Age determination based on ${ }^{210} \mathrm{~Pb}$ analysis for three paleotsunami deposit layers from Gili Trawangan is 149 years ago for layer no. 2, 117 years ago for layer no. 5, and 42 years ago for layer no. 10. Each of these paleotsunami sediment ages when converted into years from old to young is 1865, 1897 and 1972, respectively.

Layer 2 was deposited 149 years ago, related to the Bali Sea earthquake (M7.0; S8 $00^{\prime} 09.45^{\prime \prime}$, E115 $\left.29^{\prime} 56.41^{\prime \prime}\right)$. Layer 5 was deposited in 1897 and interpreted as a result of Flores Sea earthquake (M5.5; $\left.\mathrm{S}^{\circ} 47^{\prime} 59.62^{\prime \prime}, \mathrm{E} 120^{\circ} 48^{\prime} 03.5^{\prime \prime}\right)$ or Sulu Sea earthquake ( $M 8.5 ; 70 \mathrm{~km} \mathrm{NW}$ of Basilan Island) in 1897 , while layer 10 was deposited 42 years ago and probably associated with 1977 Waingapu-Sumba earthquake in 1977 (M8.0; S11 ${ }^{\circ} 5^{\prime} 39.34^{\prime \prime}$, E118 27'50.86"; Fig. 2).

\section{Conclusions}

The results of age determination by ${ }^{210} \mathrm{~Pb}$ method indicate that paleotsunami sediments from Gawah Pudak were deposited in c. 1977 and c. 1992. The three paleotsunami sediments from Gili Trawangan were deposited in c. 1865, c. 1897 and c. 1972 . This age determination reveals that paleotsunami sediments from the Lombok Island and its surroundings, from older to younger, were caused by the 1857 earthquake (epicenter in Bali Sea; M7), 1897 earthquake (epicenter in Flores Sea; M5.5 Richter Scale or Sulu Sea earthquake; $M 8.5$ where the epicenter was $70 \mathrm{~km} \mathrm{NW}$ of Basilan Island), the 1975 earthquake (Nusa Tenggara), 1977 earthquake (in Waingapu, Sumba; M8.0) and the 1992 earthquake (Flores; M7.8).

Acknowledgements We are extremely grateful to Dr. Andi Eka Sakya as Head of BMKG, Dr. Masturyono as Geophysical Division Deputy of BMKG, Dr. Mochammad Riyadi as Head of Earthquake and Tsunami Center (BMKG), Dr. Daryono as Head of Earthquake and Tsunami Mitigation Division (BMKG), the Head of Geology
Department and Dean of Faculty of Earth Sciences and Technology, Institute Teknologi Bandung (ITB), Indonesia, for the valuable opportunity given to conduct this study. We are most grateful to the following people for their help for the improvement of this paper, field work and laboratory analysis: Dr. Alfend Rudyawan, Dr. Nurcahyo Indro Basuki, Wahyu Dwijo Santoso, Nurochim, from Geology Dept. ITB, Bandung, Wakodim S.P. (BMKG of Lombok), M. Naafi Nooryawan, Ihsan Adipratama and Barokah Aliyanta, Dr. Ali Arman Lubis, Aditya Dwi Permana Putra, Untung Sugiharto, from Center for Isotopes and Radiation Application/ Pusat Aplikasi Isotop dan Radiasi (PAIR) National Nuclear Energy Agency/ Badan Tenaga Nuklir Nasional (BATAN), Jakarta.

Open Access This article is distributed under the terms of the Creative Commons Attribution 4.0 International License (http://crea tivecommons.org/licenses/by/4.0/), which permits unrestricted use, distribution, and reproduction in any medium, provided you give appropriate credit to the original author(s) and the source, provide a link to the Creative Commons license, and indicate if changes were made.

\section{References}

Arman A (2006) Constant rate of supply (CRS) model for determining the sediment accumulation rates in the coastal area using ${ }^{210} \mathrm{~Pb}$. J Coast Dev 10(1) Diponegoro University Research Center and Indonesian Oceanology Association

Arman A, Aliyanta B, Menry Y (2007) Estimation of sediment accumulation rate in jakarta bay using natural radionuclide unsupported ${ }^{210} \mathrm{~Pb}$ ”. Indones J Chem 7(3) Chemical Department, Gadjah Mada University, Yogyakarta

Boer W, van den Bergh GD, de Haas H, de Stigter HC, Gieles R, van Weering Tj CE (2006) Validation of accumulation rates in Teluk Banten (Indonesia) from commonly applied ${ }^{210} \mathrm{~Pb}$ models, using the 1883 Krakatau tephra as time marker. Mar Geol 227:263-277

Dahanayake K, Kulasena N (2008) Geological evidence for paleotsunamis in Sri Lanka. Sci Tsunami Hazards 27(2):54-61

Gelen A, Diaz O, Simón M, Herrera E, Soto J, Gómez J, Ródenas C, Beltrán J, Ramírez M (2003) ${ }^{210} \mathrm{~Pb}$ dating of sediments from havana bay. J Radioanal Nuclear Chem 256(3):561-564

Løvholt F, Kühn D, Bungum H, Harbitz CB, Glimsdal S (2012) Historical tsunamis and present tsunami hazard in eastern Indonesia and the southern philippines. J Geophys Res 117:1-19

Madsen AT, Murray AS, Andersen TJ, Pejrup M, Breuning-Madsen H (2005) Optically stimulated luminescence dating of young estuarine sediments: a comparison with ${ }^{210} \mathrm{~Pb}$ and ${ }^{137} \mathrm{Cs}$ dating. Mar Geol 214:251-268

Masturyono RM, Daryono W, Nugroho C, Weniza ASD, Gunawan IP, Yatimantoro T, Hidayanti YDS, Rahayu RH, Anggraini S, Wijaya AA (2015) Katalog tsunami Indonesia Tahun - 2014. BMKG, Jakarta, pp 13-44

Rauwenda PJ, Morley RJ, Toelstra SR (1984) Assessment of depositional environment and stratigraphy on the basis of foraminifera paleoecology. Robertson Research International Limited, Singapore, pp 54-60

Rhodes B, Tuttle M, Horton B, Doner L, Kelsey H, Nelson A, Cisternas M (2006) Paleotsunami research. EOS 87(21):205-209

Sanchez-Cabeza JA, Masque P, Ani-Ragolta I, Merino J, Frignani M, Palanques A, Puig P (1999) Sediment accumulation rates in the southern Barcelona continental margin (NW Mediterranean Sea) derived from ${ }^{210} \mathrm{~Pb}$ and ${ }^{137} \mathrm{Cs}$ chronology. Prog Oceanogr 44:313-332 
Tuttle MP, Ruffman A, Thane A, Jeter H (2004) Distinguishing tsunami from storm deposits in eastern North America: the 1929 Grand Banks tsunami versus the 1991 Halloween storm. Seismol Res Lett 75(1):117-131

Visher GS (1969) Grain size distributions and depositional processes. J Sediment Petrol 39(3):1074-1106
Yawsangratt S, Szczuciński W, Chaimance N, Chatprasert S, Majewski W, Lorenc S (2012) Evidence of probable paleotsunami deposits on Kho Khao Island, Phang Nga Province, Thailand. Nat Hazards 63:151-163 